\title{
Development of Infrastructure And Economic Growth of Papua Province
}

\author{
Siti Munawaroh ${ }^{1^{*}}$, Tri Haryanto ${ }^{2}$ \\ ${ }^{1,2}$ Airlangga University
}

\section{Article Information}

History of article:

Received June 2020

Approved February 2021

Published March 2021

\begin{abstract}
A B S TRACT
Efforts are being make equitable development through accelerated infrastructure development by providing quality infrastructure facilities and services. The government continues encourage the development of damaged infrastructure in order to increase economic growth, especially areas do not have good access. The purpose this study is determine the effect of infrastructure development on economic growth Papua Province. This study uses panel data regression with the Random Effect Model. Infrastructure data used this study are road infrastructure, educational infrastructure, health infrastructure from 29 districts / cities period 2011-2018. The results is road infrastructure and educational infrastructure have a positive and significant influence economic growth, while health infrastructure have a positive but not significant effect economic growth Papua Province. The regional government must be increase the quantity and quality of teaching staff, services and health facilities at regions isolated.
\end{abstract}

Keywords: Infrastructure, Economic Growth, Panel Data

JEL Classification Code: C23, H54, O47

(C) 2021 MediaTrend

Author correspondence:

E-mail: munawarohs94@yahoo.com

DOI: http://dx.doi.org/10.21107/mediatrend.v16i1.7454

2460-7649 ๑ 2020 MediaTrend. All rights reserved. 


\section{INTRODUCTION}

Development in Papua Province continues to be encouraged in the context of equitable development with commitment and efforts made to continue the development of all sectors, one of which is the acceleration of infrastructure development, namely roads, educational facilities and health facilities (Khan et al., 2020). However, until now the development has not been evenly distributed to remote villages, resulting in the problem of inequality in development between districts in Papua Province. Efforts have been made by the government to provide quality infrastructure facilities and services, both in the form of regulations with a regulatory framework as well as an investment framework through rehabilitation and capacity building of damaged infrastructure facilities as well as new development (Law et al., 2011). It is hoped that the regulatory policy framework and investment framework will increase the availability of infrastructure facilities and services.

In 2018, it was noted that the roads that have been built are $31,075 \mathrm{~km}$ long in good, moderate, light and heavily damaged condition. The length of roads in good condition dominates, meaning that the program for accelerating infrastructure development has progressed although slightly because there are still some districts that are still isolated. The availability of adequate roads is an urgent need for the Papua Province, which is geographically difficult. Access to transportation, especially good roads, will facilitate equitable distribution of education, health, distribution of goods and services to meet people's needs. One of the basic human needs is education. Education is a factor that reflects the quality of human resources, when viewed from the human side of development in several districts in Papua Province is still low to date.

Efforts that the government can make to improve the quality and competitiveness of human resources in Papua
Province are by building quality educational facilities in every remote area. This is important for the government to do so that every community can access quality and easy education facilities. The education infrastructure in Papua Province tends to experience various developments. The highest development was in 2015 in the construction of 7,354 junior high school buildings. To improve the quality of population health, the Papuan provincial government seeks to improve health facilities and infrastructure accompanied by adequate health personnel both in quality and quantity. This effort aims to make health service places easily accessible at a cost that is affordable to the community (Tambo et al., 2019). This needs to be done because there are still many districts in Papua Province that still do not have adequate health services. In 2016, the number of health centers was dominated by 3,085 units.

In this study using the theory of economic growth and infrastructure. First, the neoclassical growth theory states that output growth results from one or more of three factors, namely an increase in the quantity and quality of labor (through population growth and education), an increase in capital (through savings and investment), and an increase in technology. The neoclassical economic growth states the accumulation of physical capital, labor as an important driver of economic growth in the short term, while technological progress is the main determinant of economic growth in the long run. In the long run, the human capital stock is also one of the key factors driving economic growth. Second, infrastructure development is the main driver in countries of economic growth and poverty reduction. Infrastructure development is considered as a means of increasing the quality and quantity of economic growth and community welfare. Infrastructure in economics is a form of public capital formed from investments made by the government which include: roads, bridges, 
and sewer systems.

Infrastructure includes social infrastructure (such as schools and hospitals) and economic infrastructure (such as network utilities) which includes energy, water, transportation, and digital communications (Olaoye et al., 2020). Presidential Regulation Number 122 of 2016 describes the types of priority infrastructure regulated by the government including transportation infrastructure, road infrastructure, irrigation infrastructure, drinking water infrastructure, waste water infrastructure, waste facilities, telecommunications and informatics infrastructure, electricity infrastructure, oil and gas infrastructure, educational facilities infrastructure, regional infrastructure, tourism infrastructure and health infrastructure. Palei (2015) states that the infrastructure factor is determined mainly by the quality of roads which can affect economic growth. Warsilan and Noor (2015) state that health infrastructure (puskesmas) and road infrastructure play an important role in increasing economic growth. in the city of Samarinda. Rahayu \& Soleh (2017) say roads have an influence on economic growth while education infrastructure has a negative effect on Jambi's economic growth.

Suripto \& Lestari (2019) stated that road infrastructure has no effect on GRDP, education infrastructure and health infrastructure have a positive and significant effect on GRDP in Indonesia. Health infrastructure does not have a significant effect on economic growth in East Java. Based on previous empirical studies, it is evident that economic progress has led to an increase in people's welfare, which is reflected not only in increasing income, but also in improving various other social and economic indicators. The steps that have been taken by the government in accelerating infrastructure development in Papua Province for the 2011-2018 period have increased so that this research only focuses on road infrastructure, education infrastructure (educational facilities) and health infrastructure (health facilities) with the aim of knowing their effects on growth. economy in Papua Province.

Banerjee et al., (2020) paper estimates the effect of access to transportation networks on regional economic outcomes in China over a twenty-year period of rapid income growth. It addresses the problem of the endogenous placement of networks by exploiting the fact that these networks tend to connect historical cities. Our results show that proximity to transportation networks have a moderately sized positive causal effect on per capita GDP levels across sectors, but no effect on per capita GDP growth. We provide a simple theoretical framework with empirically testable predictions to interpret our results. We argue that our results are consistent with factor mobility playing an important role in determining the economic benefits of infrastructure development.

Khan et al., (2020) investigate the role of infrastructure in the economic growth of South Asia. To overcome the shortcomings in previous studies, we analyzed the economic growth in a more comprehensive infrastructure framework by introducing a composite index of infrastructure, which includes more than thirty indicators. The pooled mean group estimator' results suggest a positive impact of infrastructure on economic growth. The inclusion of control variables is robust to our analysis. We advocate several policy recommendations.

\section{METHODOLOGY}

This study uses secondary data sourced from the Papua Province Central Statistics Agency and related agencies in 29 districts / cities of Papua Province for the 2011-2018 period. Economic growth is proxied by using the Gross Regional Domestic Product at 2010 Constant Prices (GRDP) as the dependent variable while the independent variable is infrastructure including roads, educational facilities and 
health facilities. This study also includes a control variable, namely investment proxied by capital expenditure and labor. The analysis technique used in this research is panel data regression analysis. Panel data is data that is the result of observations on several cross-sections and time series.

Panel data regression has several advantages (Asteriou, 2009). First, panel data is a combination of time series and cross section data which is able to provide more data so that it will produce a greater degree of freedom. Second, combining information from time series and cross section data can solve problems that arise when there are ommited-variable problems. Third, the ability to control the heterogeneity problem makes panel data usable to test and build more complex behavioral models. There are three methods that can be used to process panel data, first using Pooled Least Square (PLS), second using fixed effect (FEM), and third using random effect (REM).

The Pooled Least Square (PLS) approach simply combines all time series and cross section data. This method only combines time series and cross section data without considering individual dimensions and time. The Pooled Least Square (OLS) method assumes that the intercept and slope of the regression equation are considered constant. With this Fixed Effect Method (FEM) approach, there is the possibility of facing the problem of omitted variables. Omitted variables bring changes to the intercept time series and cross section. This approach is a panel data estimation technique using dummy variables to capture the difference in intercept between cross sections. The Random Effect Method (REM) approach is a panel data estimation technique that takes into account that the disturbance variables are interrelated both between time and between individuals. This REM approach is a variation of the general least square estimation.

Selection of the estimation model in the panel method, in determining the use of the method between Pooled Least Square (OLS) or FEM (fixed effect method) using the redundant test. Redundant test is used to select techniques with the Pooled Least Square (PLS) or Fixed Effect Model (FEM) model. If the result of Prob Obs * Square value is less than 0.05 , the FEM model is accepted, but if Prob Obs * square is more than 0.05 then the PLS model is accepted.

The Hausman test is used to choose between the fixed effect method (FEM) or the random effect method (REM). The Hausman test can be done using the Correlated Random Effect - Hausman Test, so that the Chi-Sq probability value will be obtained (Apergis \& Poufinas, 2020). After obtaining the Chi-Sq probability value, then comparing the Chi-Sq probability value with a level of significance of 5 percent (0.05). If the results of the Chi-Sq probability value <level of significance of 5 percent (0.05) then $\mathrm{H}_{0}$ is rejected and accepts $\mathrm{H} 1$, which states that the Fixed Effect (FEM) model must be selected. If the results of the Chi-Sq probability value> level of significance of 5 percent $(0.05)$ then $\mathrm{HO}$ is accepted and $\mathrm{H} 1$ is rejected, which states that the Random Effect (REM) model must be selected.

The specifications of the equation model in this study are as follows:

PDRBit $=\beta_{0}+\beta_{1} B M_{i t}+\beta_{2} L_{i t}+$

$\beta_{3} J L N_{i t}+\beta_{4} P E N D_{i t}+\beta_{5} K E S H_{i t}+\varepsilon_{i t}$

where PDRB is Gross Regional Domestic Product; $B M$ is capital expenditure; $L$ is labor; JLN is road length; PEND is number of educational facilities; KESH is number of health facilities; $\beta 0, \beta 1, \ldots, \beta 5$ is slope; $\varepsilon$ is error term; it is District / City i in year $t$ to $i=1,2, \ldots, n$. Estimation of parameters using STATA.

\section{RESULTS AND DISCUSSION}

Differences in geographical conditions, development policies result in dif- 
ferences in the economy in each region. Therefore, each regency / city in Papua Province has differences regarding economic conditions with different gross regional domestic product values and growth of different gross regional domestic products. The economic growth of Papua Province in 2011-2018 was the lowest even negative in 2011 amounting to -4.28 and the highest in 2016 amounting to 9.14. The increase or decrease in economic growth in Papua Province is caused by the production of gold and copper ore PT Freeport Indonesia, which is located in Mimika Regency, which has been supporting economic growth.

In the past few years, PT Freeport Indonesia has experienced both internal and external problems so that this will affect economic growth. Papua Province has abundant natural resources that can be used to support economic growth apart from mining, for example agriculture, fisheries, which should be done by the central government, local governments, related agencies and indigenous Papuan leaders to work together to maximize the fishery business development and development programs that have been implemented such as Central fish seed centers, coastal fish seed centers, fishing ports and fish landing bases (PPI) to be able to encourage growth.
Investment proxied by capital expenditure is one of the government investments in the public sector for the welfare of society by providing goods and services needed by the community. Investment is usually synonymous with investment with the aim of obtaining profits in the future. However, this definition cannot be equated in the context of investment in the public sector. Government investment is the placement of a number of funds or goods in the long term to obtain economic, social and other benefits.

The Government Accounting Standard Statement No. 06 concludes that investment (capital expenditure) is expenditure on the procurement of assets that can provide benefits, both economic, social and other benefits, for more than 12 months (one year) with the aim of improving the welfare of the community. public investment needs more emphasis and attention than routine expenditures. Investment expenditure (capital expenditure) has a long-term effect, whereas routine expenditure has a short-term effect. If there are errors in making investment decisions (capital expenditures), it will have an impact on the current year and subsequent years (Olaoye et al., 2020).

Investment is the first step in production activities which is essentially the first step in economic development activi-

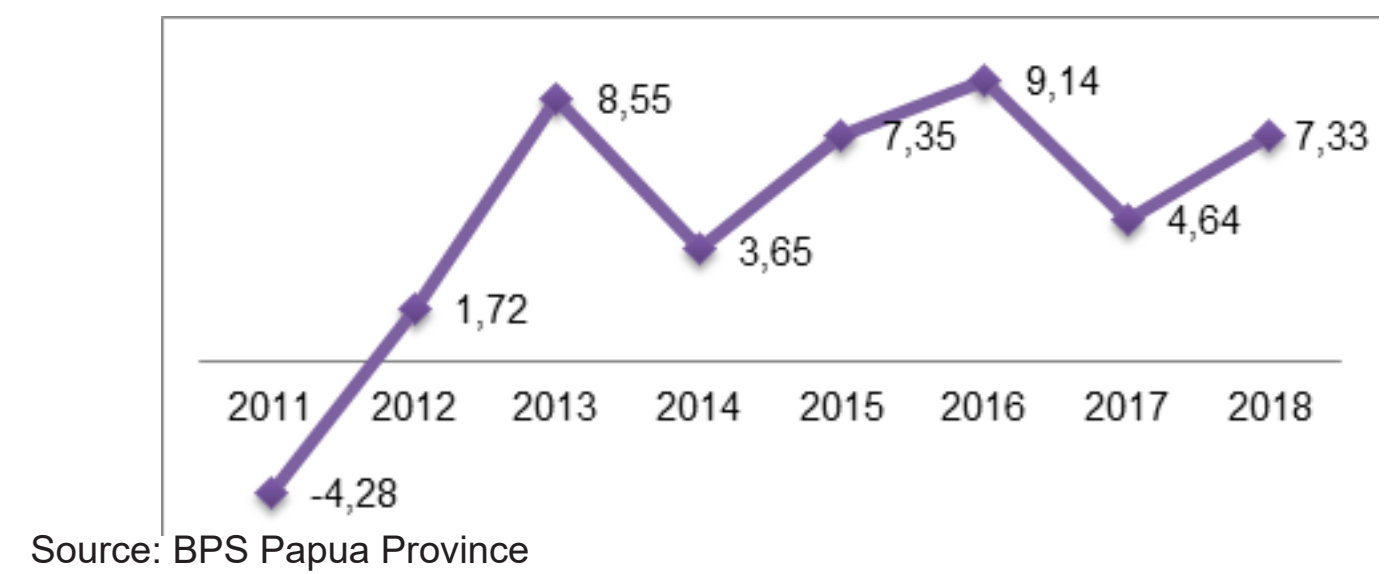

Figure 1.

Papua Province Economic Growth Average 2011-2018 
ties (Apergis \& Poufinas, 2020). The dynamics of investment affect the level of development and economic growth. So that in an effort to grow the economy, every country must try to create a climate that can stimulate investment. Therefore, investment needs to get more attention related to its performance and benefits. Thus, investment (capital expenditure) in the public sector needs to get more attention with regard to spending aimed at implementing government programs / activities related to the provision of goods / services to the community in order to improve people's welfare, which is expected to encourage economic growth in a country and region. Capital expenditures are usually directed more towards infrastructure development that supports economic growth, such as building roads to production areas.

The greater the allocation of capital expenditures shows that local governments have various kinds of programs that they want to achieve. The largest portion of capital expenditure in Papua Province is for road, irrigation and network construction per year. The absorption capacity of spending on land per year appears to be the lowest in the composition of capital expenditures. Polemics that occur in land disputes often cause delays in the absorption of capital expenditures for land, so the absorption capacity is very low. One of the dominant factors that causes this condition to occur is the lack of ownership of land certificates in the community, both individually and in groups (customary land) (Afzal et al., 2011). This has been a serious concern of the Papuan government so far, however, due to the incompleteness of the land certification programs being implemented, this problem has persisted to this day. Realization of capital expenditure in Papua Province for the 2011-2018 period was the highest in 2015 at 16.77 percent, this is because development programs are being intensively carried out in various districts or regions of Papua Province.

Every year the workforce in Papua Province has fluctuated in the period August 2011-2018. It can be seen that the pattern of the distribution of the working population in Papua province is the same as the distribution pattern of the workforce. Does not depend on the population of working age although in general this applies. The number of working age population that is superior in quantity, such as in urban areas, does not necessarily have a large number of people who work either due to the low quality of labor, low education and expertise, the type of work done does not require high skills and topographical conditions make the population work absorbed differently. The highest workforce in 2018 was $1,777,207$ people, it can be seen that

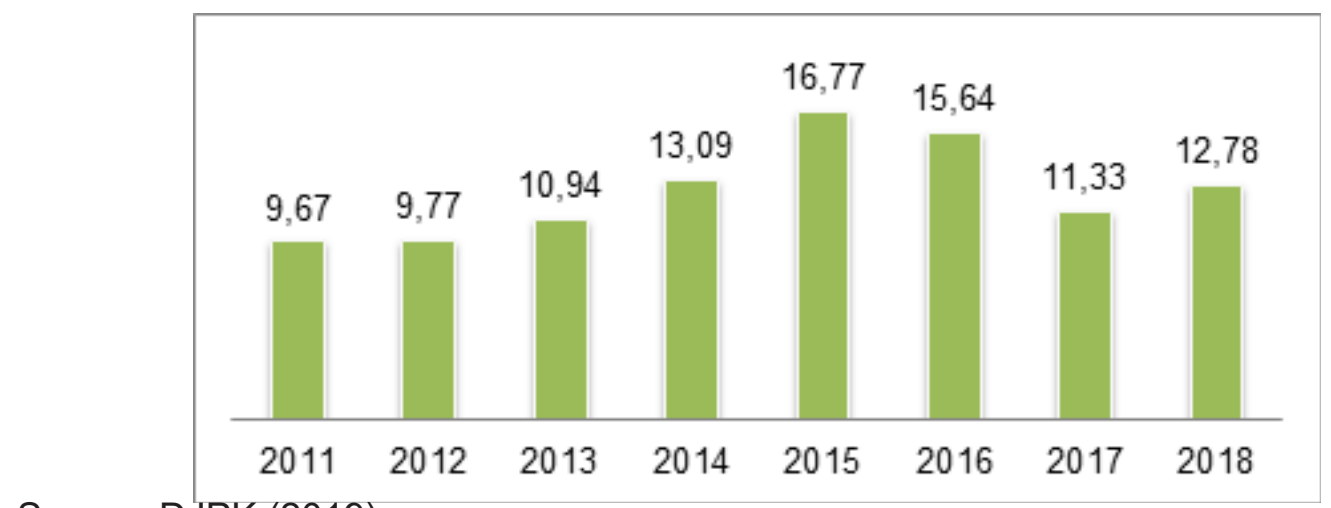

Source: DJPK (2019)

Figure 2.

Capital Expenditure Papua Province 2011-2018 
Papua Province is a destination for finding work for the community including those from outside Papua, as well as big cities that have various kinds of labor-intensive industries that require a lot of labor.

Infrastructure development is evidence of the development of a region / region. The main reason that is very important in infrastructure development according to economic integration is that the availability of infrastructure affects investment and trade activities. The nature and types of infrastructure required by an area are influenced by natural characteristics and the typical population distribution pattern of the area. Infrastructure is not only needed to increase competitiveness in order to encourage more investment, production and trade activities, but also to accelerate equitable development so that poverty and unemployment rates can be lowered.

Development in Papua Province often experiences delays in its progress and does not comply with the predetermined schedule. This is due to the ever-changing weather (rain), different terrain conditions or land contours in the field, the existence of materials that are difficult to obtain and the security is not conducive. Besides that, there are still other problems, namely the difficulty of land acquisition. Land acquisition is quite a cruisial matter, so it requires a sociological and cultural approach with local customary community leaders. Cur-

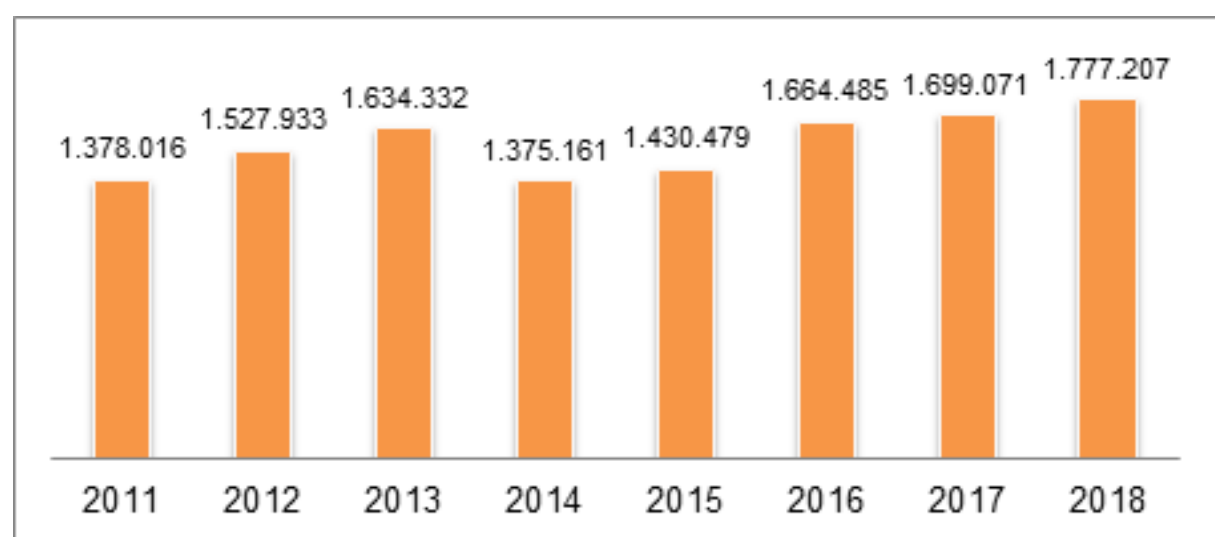

Source: BPS of Papua Province

Figure 3.

Workers in Papua Province 2011-2018

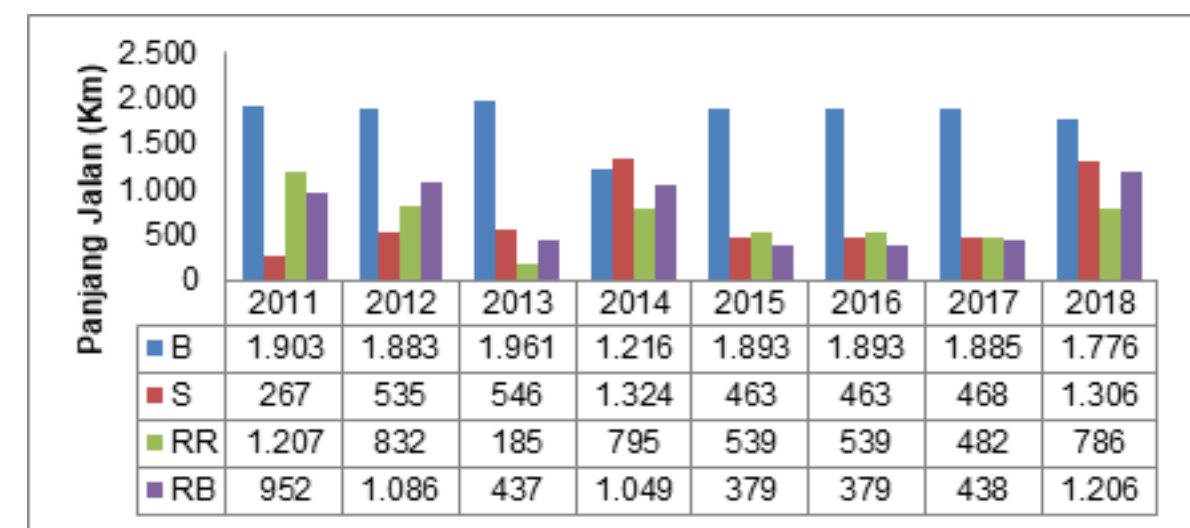

Source: BPS of Papua Province

Figure 4.

Road Infrastructure in Papua Province 2011-2018 
rently, development in Papua Province has progressed compared to previous years because several traditional leaders in certain areas have agreed to work together to build a better Papua. This condition was previously a problem and challenge for development in this province.

Road infrastructure is based on data from 2011-2018, it is noted that the length of roads in good condition is more dominant, meaning that the program to accelerate infrastructure development has progressed although slightly because there are still some districts that are still isolated, such as Nduga Regency, Intan Jaya Regency, Deiyai Regency from 2011-2017. who do not yet have roads in good condition. The availability of adequate roads is an urgent need for the Papua Province, which is geographically difficult. Overall, the length of roads in Papua Province is based on good and moderate conditions. It is sufficient to maximize development in areas that still have minimal access to transportation, especially roads because roads have an important role in the distribution of goods and services (Nedić et al., 2020). In this case the road has a strategic function as a link between one region and another and its benefits are greatly felt in order to improve the economy.
Educational facilities generally include all facilities that are directly used and support the educational process such as buildings, study rooms or classes, educational equipment or media, desks, chairs and so on. Meanwhile, what is meant by infrastructure is those that indirectly support the education process, such as yards, gardens or school parks or roads leading to schools (Hartwig, 2010). Educational infrastructure (educational facilities) in almost all districts of Papua Province already have school buildings starting from kindergarten, elementary, junior high and high school. Evenly, the construction of school buildings in all districts / cities must be balanced with the quality and quantity of teaching staff so that the available educational facilities can be utilized properly and maximally so as to increase development from the human side (human capital) which is the key to long-term economic growth (Xu \& Li, 2020).

Health is an important foundation for humans, because without good health humans will find it difficult to carry out their daily activities. The low level of health of human resources will further reduce productivity so that the output produced from a region / region both in quantity and quality will have an impact on economic growth.

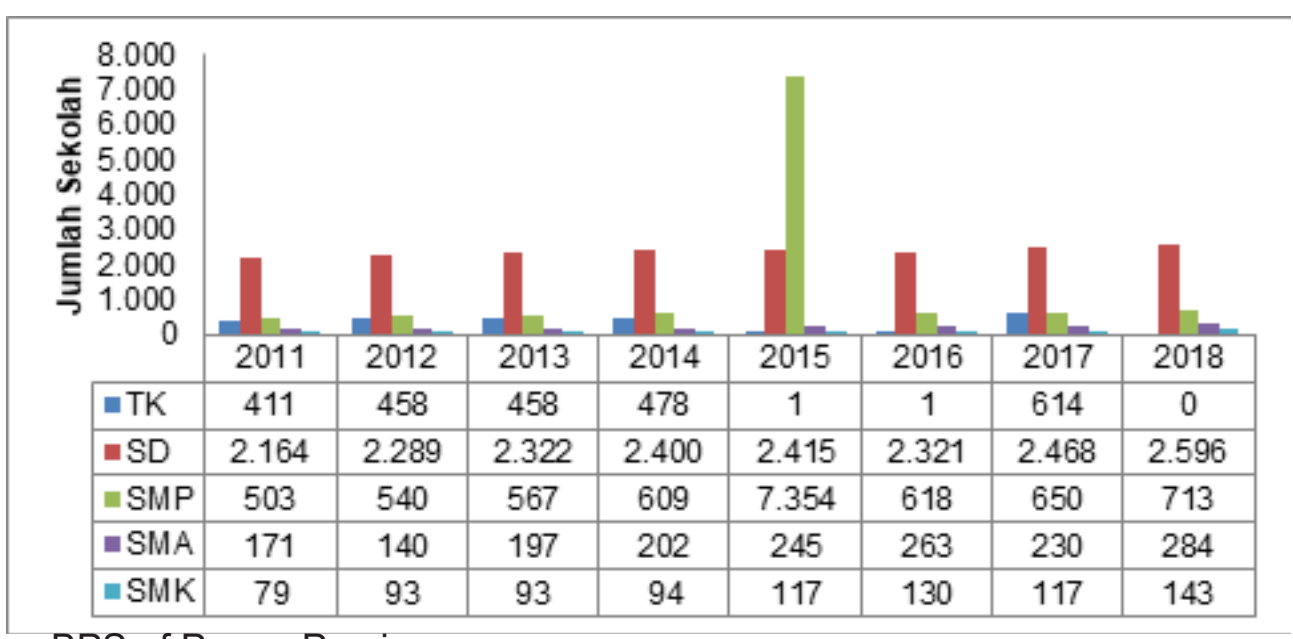

Source: BPS of Papua Province

Figure 5.

Educational Facilities in Papua Province 2011-2018 
Efforts that can be made by the government to maintain the health of its inhabitants so that they are always in a healthy condition both body and soul is to ensure the availability of adequate health facilities for the entire community. The availability of adequate health facilities can make it easier for people to access good health services when they need it and it is hoped that it will keep the community in prime condition so that both social and economic activities are not disturbed.

The results of the F-restricted test show that the probability value of $F$ statistic is 0.0000 , less than $\alpha 5 \%$. The decision to test the hypothesis is that $\mathrm{HO}$ is rejected, so it can be concluded that the better method to choose is FEM. Furthermore, the Hausman test results show that the Chi-Square Statistics (x2) - 16.03 is less a $5 \%$. Therefore, the decision is that $\mathrm{H}_{0}$ is not rejected, so it can be concluded that the REM method is better to use than FEM.
The results of panel data regression using REM shows the investment variable (BM) has a probability value of 0.045 which means significant at a $5 \%$ with a coefficient of 0.1019 , which means that the investment variable has an influence on economic growth. A positive value on the investment variable indicates that economic growth will increase by 0.1019 percent when the investment variable increases by 1 percent. Labor has a probability value of 0.000 which means significant at a $1 \%$ with a coefficient of 0.0436 , which means that labor has an influence on economic growth. A positive value on the labor variable indicates that economic growth will increase by 0.0436 percent if the labor variable increases by 1 percent. Road infrastructure has a probability value of 0.050 which means significant at $\alpha 5 \%$ with a coefficient of 0.0428 , which means that the road infrastructure variable has an influence on economic growth. A positive

Table 1.

Panel Data Regression Results

\begin{tabular}{|c|c|c|c|}
\hline \multirow{2}{*}{ Variabel } & OLS & FEM & REM \\
\hline & \multicolumn{3}{|c|}{ Dependent variable: GRDP } \\
\hline \multirow[t]{2}{*}{ Cons } & $8,3831^{* *}$ & $17,1200^{* * *}$ & $17,3517^{* * *}$ \\
\hline & $(3,6249)$ & $(1,2872)$ & $(1,2149)$ \\
\hline \multirow[t]{2}{*}{ Capital Expenditure } & 0,2135 & $0,1278^{* *}$ & $0,1019^{* *}$ \\
\hline & $(0,1369)$ & $(0,0505)$ & $(0,0508)$ \\
\hline \multirow[t]{2}{*}{ Labor } & $0,1502^{* *}$ & $0,0413^{* *}$ & $0,0436^{* * *}$ \\
\hline & $(0,0612)$ & $(0,0177)$ & $(0,0122)$ \\
\hline \multirow[t]{2}{*}{ Road Length } & 0,0841 & $0,0419^{* *}$ & $0,0428^{* *}$ \\
\hline & $(0,0560)$ & $(0,0180)$ & $(0,0218)$ \\
\hline \multirow{3}{*}{$\begin{array}{l}\text { Number of Educational } \\
\text { Facilities }\end{array}$} & & & \\
\hline & $0,7929^{* * *}$ & 0,0518 & $0,0956^{* * *}$ \\
\hline & $(0,0969)$ & $(0,0370)$ & $(0,0288)$ \\
\hline \multirow{3}{*}{$\begin{array}{l}\text { Number of Health } \\
\text { Facilities }\end{array}$} & & & \\
\hline & $0,4070^{* * *}$ & $-0,0025$ & 0,0299 \\
\hline & $(0,1089)$ & $(0,0347)$ & $(0,0253)$ \\
\hline Restricted F test & & 000 & \\
\hline Hausman test & & \multicolumn{2}{|c|}{$-16,02$} \\
\hline
\end{tabular}


value on the road infrastructure variable indicates that economic growth will increase by 0.0428 percent when road infrastructure increases by 1 percent. Educational infrastructure has a probability value of 0.001 which means that it is significant at $\alpha 1 \%$ with a coefficient of 0.0956 , which means that the education infrastructure variable has an influence on economic growth. A positive value on the education infrastructure variable indicates that economic growth will increase by 0.0956 percent when the education infrastructure increases by 1 percent. The health infrastructure variable has a probability value of 0.239 which means it is not significant with a coefficient value of 0.0299 .

Labor has a positive and significant effect on economic growth. This positive effect shows that an increase in labor will have an effect on economic growth. With a significance result of 0.000 and a coefficient of 0.0436 , this means that every 1 percent increase in labor will increase economic growth by 4.36 percent, assuming other independent variables are constant. The results of this study are in accordance with the neoclassical growth theory which states that the factors of economic growth are an increase in the quantity and quality of labor (through population growth and education), an increase in capital (through savings and investment).

Road infrastructure has a positive and significant effect on economic growth. This positive effect shows that an increase in road infrastructure will affect economic growth. With a significance result of 0.050 and a coefficient of 0.0428 , this means that every 1 percent increase in road infrastructure will increase economic growth by 4.28 percent, assuming other independent variables are constant. The results of this study support the research of Rahayu \& Soleh (2017) which state that roads have an influence on economic growth.

Educational infrastructure has a positive and significant effect on economic growth. This positive effect shows that an increase in education infrastructure will affect economic growth. With a significance result of 0.001 and a coefficient of 0.0956 , this means that every 1 percent increase in education infrastructure will increase economic growth by 9.56 percent, assuming other independent variables are constant. This research supports research conducted by Pranessy et al (2012), which states that educational infrastructure (number of schools) affects economic growth. Education has an important role in shaping the ability and experience as well as expertise in society to absorb modern technology and to develop capacities to create sustainable growth and development.

Health infrastructure shows a positive but insignificant impact on economic growth due to inadequate health-related data for supporters in Papua Province. In general, infrastructure development will have an impact on economic growth, either directly or indirectly. Infrastructure itself is a prerequisite for other sectors to develop as well as a means of creating relationships with one another. Empowerment of resources to build infrastructure will trigger an economic process that causes a multiplication of economic and social impacts (Setiadi 2006 in Warsilan \& Noor, 2015). Infrastructure problems are still an important problem, not only in Indonesia but in several other areas. This is important, because of its role to attract investors to increase the rate of economic growth.

To find out the role of local government in development, it can be seen from the program or policy. Papua Provincial government programs related to the development of not only infrastructure but all sectors capable of driving economic growth in each district in Papua Province include increasing human development, namely: (1) developing the quality and access to education at all channels and levels, (2) development of quality and access to health \& nutrition. Increasing the regional economy, 
namely: (1) developing strategic areas that support regional economies, (2) increasing agricultural production, forestry, fisheries, increasing food security and sovereignty and managing natural resources in a sustainable manner. Improvement of regional infrastructure, namely: (1) acceleration of intermodal transportation connectivity, (2) development and development of irrigation networks, raw water, flood control and coastal abrasion, (3) provision of housing and settlements, (4) development of strategic areas and spatial planning , (5) environmental management and natural disaster management, (6) provision of basic infrastructure (village roads and bridges, clean water, sanitation, electricity and telecommunications).

The role of local government in development is seen from its policies. Policies at the regional level are very much needed because the conditions of problems and development potentials of a region in Papua Province are generally different from one another, so the policies needed are not the same. Then the Papua provincial government established five areas for economic development based on indigenous territories in Papua Province by developing infrastructure that supports sectoral and spatial economic development. Five customary area-based economic development areas include: (1) Saireri customary area consisting of districts located in the Cenderawasih Bay Islands region, namely Biak Numfor, Supiori, Yapen Islands, and Waropen districts, (2) Mamta customary area divided into districts located along the Mamberamo river to the Pacific Ocean, namely Jayapura City, Jayapura Regency, Keerom and Mamberamo Raya, (3) The Me Pago customary area located in the western side of the Central Mountains consists of Mimika, Nabire, Paniai, Intan Jaya, Dogiyai and Deyiai Regencies, (4) The customary area of La Pago which is located in the eastern side of the Central Mountains consists of Jayawijaya, Puncak
Jaya, Puncak, Nduga, Yahukimo, Yalimo, Tolikara, Central Mamberamo, Lanny Jaya and Bintang Mountains, (5) Anim Ha customary areas which located in the southern region of Papua, namely Merauke, Asmat, Mappi and Boven Digoel districts. The acceleration of the development of strategic areas in the Papua Province is carried out by: (1) increasing the economic potential of the region, (2) accelerating the strengthening of connectivity, (3) developing the local economy, (4) strengthening the capacity of human resources and science and technology.

\section{CONCLUSIONS}

The conclusions of this study are: (1) investment, labor, road infrastructure and education infrastructure have a significant positive effect on economic growth in Papua Province while health infrastructure has a positive and insignificant effect on economic growth. Of the three infrastructures (roads, educational facilities and health facilities) that have the greatest influence on economic growth is education infrastructure because the program to accelerate the development of educational infrastructure such as school buildings has been evenly distributed throughout the districts / cities of Papua Province. (2) programs and policies in development which are contained in the government's work plan by making priority programs such as human development, regional economic enhancement, regional infrastructure improvement are appropriate. If it is related to the results of this research, the infrastructure development acceleration program has an important role in advancing the regions in Papua Province. Suggestions for the regional government to further increase the quantity and quality of teaching / teaching staff, medical personnel, especially in areas that are still underdeveloped / isolated, for example Nduga district because based on the district's infrastructure data is still minimal and maximizes cooperation 
with traditional leaders regarding the five development programs. customary territory-based economic development areas which in general have different conditions and potential problems.

\section{REFERENCE}

Afzal, M., Rehman, H. U., Farooq, M. S., \& Sarwar, K. (2011). Education and economic growth in Pakistan: A cointegration and causality analysis. International Journal of Educational Research, 50(5-6), 321-335. https:// doi.org/10.1016/j.ijer.2011.10.004

Afzal, M., Rehman, H. U., Farooq, M. S., \& Sarwar, K. (2011). Education and economic growth in Pakistan: A cointegration and causality analysis. International Journal of Educational Research, 50(5-6), 321-335. https:// doi.org/10.1016/j.ijer.2011.10.004

Apergis, N., \& Poufinas, T. (2020). The role of insurance growth in economic growth: Fresh evidence from a panel of OECD countries. The North American Journal of Economics and Finance, 53, 101217. https://doi.org/10.1016/j. najef.2020.101217

Asteriou, D. (2009). Foreign aid and economic growth: New evidence from a panel data approach for five South Asian countries. Journal of Policy Modeling, 31(1), 155-161. https://doi. org/10.1016/j.jpolmod.2008.04.012

Banerjee, A., Duflo, E., \& Qian, N. (2020). On the road: Access to transportation infrastructure and economic growth in China. Journal of Development Economics, 145, 102442. https://doi. org/10.1016/j.jdeveco.2020.102442

Hartwig, J. (2010). Is health capital formation good for long-term economic growth? - Panel Granger-causality evidence for OECD countries. Journal of Macroeconomics, 32(1), 314-325. https:// doi.org/10.1016/j.jmacro.2009.06.003

Khan, H., Khan, U., Jiang, L. J., \& Khan, M. A. (2020). Impact of infrastructure on economic growth in South Asia: Evidence from pooled mean group estimation. The Electricity Journal, 33(5), 106735. https://doi.org/10.1016/j. tej.2020.106735

Law, T. H., Noland, R. B., \& Evans, A. W. (2011). The sources of the Kuznets relationship between road fatalities and economic growth. Journal of Transport Geography, 19(2), 355-365. https:// doi.org/10.1016/j.jtrangeo.2010.02.004

Nedić, V., Despotović, D., Cvetanović, S., Djukić, T., \& Petrović, D. (2020). Institutional reforms for economic growth in the Western Balkan countries. Journal of Policy Modeling, 42(5), 933-952. https://doi.org/10.1016/j. jpolmod.2020.04.002

Olaoye, O. O., Eluwole, O. O., Ayesha, A., \& Afolabi, O. O. (2020). Government spending and economic growth in ECOWAS: An asymmetric analysis. The Journal of Economic Asymmetries, 22, e00180. https://doi.org/10.1016/j. jeca.2020.e00180

Palei, T. (2015). Assessing the impact of infrastructure on economic growth and global competitiveness. Procedia Economics and Finance, 23, 168-175.

Pranessy, L., Ridwan, N., \& Merri, A. (2012). Pengaruh Pembangunan Infrastruktur Terhadap Pertumbuhan Ekonomi Provinsi Bengkulu. Jurnal Ekonomi dan Perencanaan Pembangunan, 4(3), 49-60.

Rahayu, Y., \& Soleh, A. (2017). Pengaruh Pembangunan Infrastruktur Terhadap Pertumbuhan Ekonomi Provinsi Jambi (Pendekatan Fungsi Cobb Douglas). Jurnal Development, 5(2), 125-139.

Suripto, S., \& Lestari, E. D. (2019). Pengaruh 
Pembangunan Infrastruktur terhadap PDRB di Provinsi Indonesia. Wahana: Jurnal Ekonomi, Manajemen dan Akuntansi, 22(1), 15-27.

Tambo, E., Khayeka-Wandabwa, C., Muchiri, G. W., Liu, Y.-N., Tang, S., \& Zhou, X.-N. (2019). China's Belt and Road Initiative: Incorporating public health measures toward global economic growth and shared prosperity. Global Health Journal, 3(2), 46-49. https://doi. org/10.1016/j.glohj.2019.06.003

Warsilan, W., \& Noor, A. (2015). Peranan Infrastruktur terhadap Pertumbuhan Ekonomi dan Implikasi pada Kebijakan Pembangunan di Kota Samarinda. MIMBAR, Jurnal Sosial dan Pembangunan, 31(2), 359-366.

Xu, Y., \& Li, A. (2020). The relationship between innovative human capital and interprovincial economic growth based on panel data model and spatial econometrics. Journal of Computational and Applied Mathematics, 365, 112381. https://doi.org/10.1016/j. cam.2019.112381 